\title{
ON THE POSSIBILITY OF TESTING MIOCENE CLAY FROM CRACOW AREA USING WEIGHT SOUNDING TEST (WST)
}

\author{
SEBASTIAN OLESIAK \\ AGH University of Science and Technology, Faculty of Mining and Geoingeenering, \\ Department of Geomechanics, Civil Engineering and Geotechnics, \\ al. Mickiewicza 30,30-059 Kraków, pawilon A1, pok.309, tel. 1261747 69, e-mail: olesiak@agh.edu.pl
}

\begin{abstract}
Polish standards concerning field investigation with the use of a Weight Sounding Test (WST) probe give interpretation of results for non-cohesive soils only. The lack of such interpretation for cohesive soils excludes this testing equipment from use. This paper presents the results of geotechnical site investigation and laboratory tests performed for Miocene clays in Carpathian Foredeep in the Cracow area. Based on the analysis of the results a correlation was determined between the characteristic values for the WST probe (number of half-turns $N_{W S T}$ ) and the selected properties of Miocene clays. The article is an attempt to create a complete interpretation of test results obtained for cohesive soil with WST equipment.
\end{abstract}

Key words: geotechnical engineering, weight sounding test WST, geotechnical site characterization, soil laboratory investigation, undrained shear strength

\section{INTRODUCTION}

In-situ tests are more advantageous than the laboratory tests owing to faster proceedings, the capability to detect minor discontinuities in soil and lower costs. Nevertheless, in order to carry out field tests with the use of geotechnical probes, a proper calibration of the probe is required. Relevant, reliable and universal information about the interpretation of the results obtained for both cohesive and non-cohesive soil should be available to the probe user. It refers to both simple manual tools and the most technically advanced automatic probes.

Weight Sounding Test (WST) probe was developed by the Geotechnical Department of Swedish Railways in 1915 [16]. Currently, the probes are used for the investigation of all types of soil, mainly for evaluating the thickness and range of the layers arranged one above another and for assessment of selected soil characteristics for project-related purposes. In Europe, the WST probe is most commonly used in Scandinavia, especially Sweden and Finland [6], [14], [27]. However, in Asia, the probe is considered to be a standard research tool used in assessing the causes of disasters associated with earthquakes and the accompanying phenomenon of soil liquefaction. The relation stated by Inada [9], subject to various kinds of modifications [18], [37], [34], has been used for interpreta- tion of results since the early 1960's. The probe was used, among others, in Turkey [34], Iran [7], [31], India [32], Sumatra [17] and Japan [13], [15], [28], [33], [35], and more recently in New Zealand, in conjunction with the strong earthquake which struck the country in 2010 [2], [3], [29], [36]. Despite the fact that the probe has already been in use for almost 100 years, no standard data interpretation rules have been developed so far (except for a small group of non-cohesive soils) [25].

Research studies into the use of the WST probe for the investigation of cohesive soil commenced in 2008 [19], and were continued in subsequent years [1], [20][22]. This paper describes the studies carried-out between 2011 and 2012, and is a kind of report on the 5th stage of the studies on the calibration of the WST probe. In the first instance, calibration tests were conducted only on a small group of cohesive stiff soil composed of upper Miocene clays of Carpathian Foredeep.

\section{DESCRIPTION OF THE REGION SELECTED FOR INVESTIGATION}

Miocene clays occur commonly and almost over the whole surface of the Carpathian Foredeep. Their roof appears sometimes directly on the land surface 
under a thin layer of organic soil, but more frequently below a thin cover of younger quaternary deposits. The deposits of clay in the Cracow region are of a varying thickness, and vary considerably from few $\mathrm{cm}$ on terrain uplifts up to ten meters in depressions [10].

For practical reasons, the scope of use of the WST probe for cohesive soil is limited to a depth of 6-7 m. This limitation is caused by the friction of soil on designated. During the field tests, 20 WST probings were set up in the grid of $4 \times 4 \mathrm{~m}$ and 12 test boreholes were made. A layout of the test field is shown in Fig. 1.

In 6 test boreholes (I-VI) of a depth of $5.5 \mathrm{~m}$, additional tests of undrained shear strength $c_{f v}$ and remoulded shear strength $c_{r v}$ were carried out with a $1 \mathrm{~m}$ step of the depth using Field Vane Test (FVT) probe. The results of tests made with the use of FVT probe

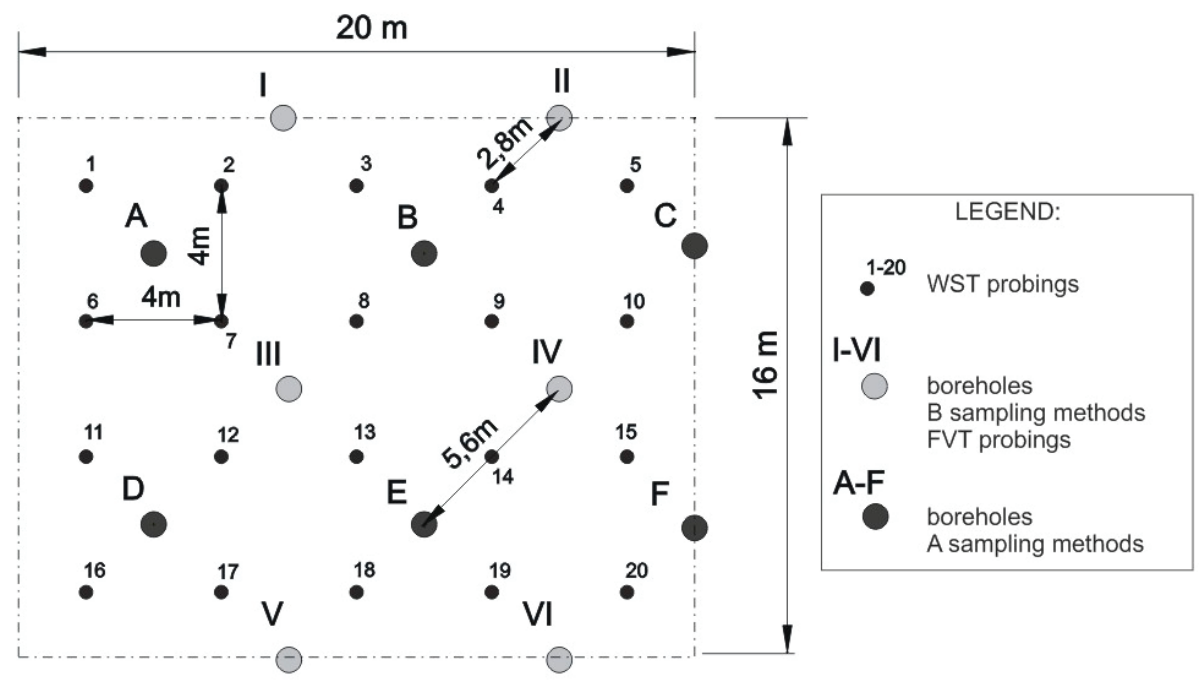

Fig. 1. Layout of test field

drilling rod, which causes a number of half-turns and is artificially increased below this depth [19], [30]. When selecting subsequent test stands, efforts were made to choose locations in which the Miocene clays occurred directly on the land surface, limiting the scope of probing and drilling to a depth of $6 \mathrm{~m}$.

The tests were carried out in the village of Tenczynek, located around $30 \mathrm{~km}$ west from Cracow. When constructing new houses in this region, Miocene clays occurring almost directly on the land surface were found. The selected research area is planar, and the differences in altitude observed on the plot meant that the depth at which the tests were to be conducted could not exceed $0.5 \mathrm{~m}$. The roof of the Miocene clays lies at a depth of approximately $0.5 \mathrm{~m}$ below ground level under a layer of organic soil. Drillings performed in the scope of field tests did not reach the thill of the clay layer.

\section{GEOTECHNICAL SITE CHARACTERIZATIONS}

A rectangular test field of width and length of 16 and $20 \mathrm{~m}$, respectively, and surface of $320 \mathrm{~m}^{2}$ was comprising average undrained shear strength of all 6 boreholes and soil sensitivity indices determined in accordance with [5] are given in Table 1. In addition, samples for further laboratory tests (category B sampling methods) were taken from the same boreholes at $1 \mathrm{~m}$ depth intervals. In the other 6 boreholes $(\mathrm{A}-\mathrm{F})$, samples for strength tests (category A sampling methods) were taken at $1 \mathrm{~m}$ depth intervals.

In the scope of WST probe calibration tests, 20 probings were made to a depth of $5.5 \mathrm{~m}$, and as provided in papers [1], [19]-[22], half-turns were counted for every $10 \mathrm{~cm}$ of probe penetration.

For probe penetration under a load of less than $1 \mathrm{kN}$, the following substitute numbers of half-turns were assumed: 0 for $1.0 \mathrm{kN},-1$ for $0.75 \mathrm{kN},-2$ for $0.50 \mathrm{kN}$, -3 for $0.25 \mathrm{kN},-4$ for $0.0 \mathrm{kN}$. The same approach was presented in previous studies [1], [19]-[22] concerning calibration tests of WST probe.

The results of the probing are given in Fig. 2. The graphs, in addition to the curve showing the averaged results of 20 probings, also contain the curves presenting the minimum and maximum values obtained during probing (Fig. 2a) and an average deviation value (Fig. 2b).

The number of half-turns varies from $-3(0.25 \mathrm{kN})$ to 20 within the profile of tested clays. A gradual 
Table 1

Results of tests carried out with the use of FVT probe

\begin{tabular}{|l|c|c|c|c|c|}
\hline \multicolumn{1}{|c|}{ Depth } & $1 \mathrm{~m}$ & $2 \mathrm{~m}$ & $3 \mathrm{~m}$ & $4 \mathrm{~m}$ & $5 \mathrm{~m}$ \\
\hline $\begin{array}{l}\text { Undranied shear strength } \\
c_{f v}[\mathrm{kPa}]\end{array}$ & 78.3 & 118.3 & 129.2 & 156.7 & 170.0 \\
\hline $\begin{array}{l}\text { Remoulded shear strength } \\
c_{r v}[\mathrm{kPa}]\end{array}$ & 27.5 & 42.5 & 46.7 & 64.2 & 79.2 \\
\hline $\begin{array}{l}\text { Soil sensitivity index } \\
S_{t v}=c_{f v} / c_{r v}\end{array}$ & 2.85 & 2.78 & 2.77 & 2.44 & 2.15 \\
\hline Sensitivity [26] & low & low & low & low & low \\
\hline
\end{tabular}

a)

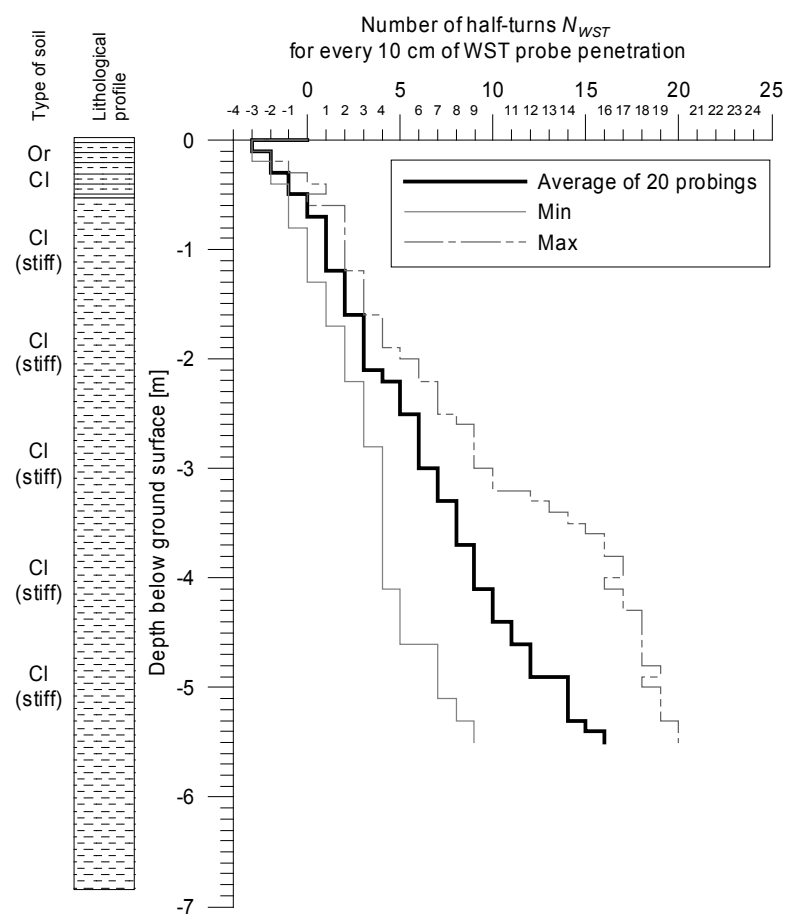

b)

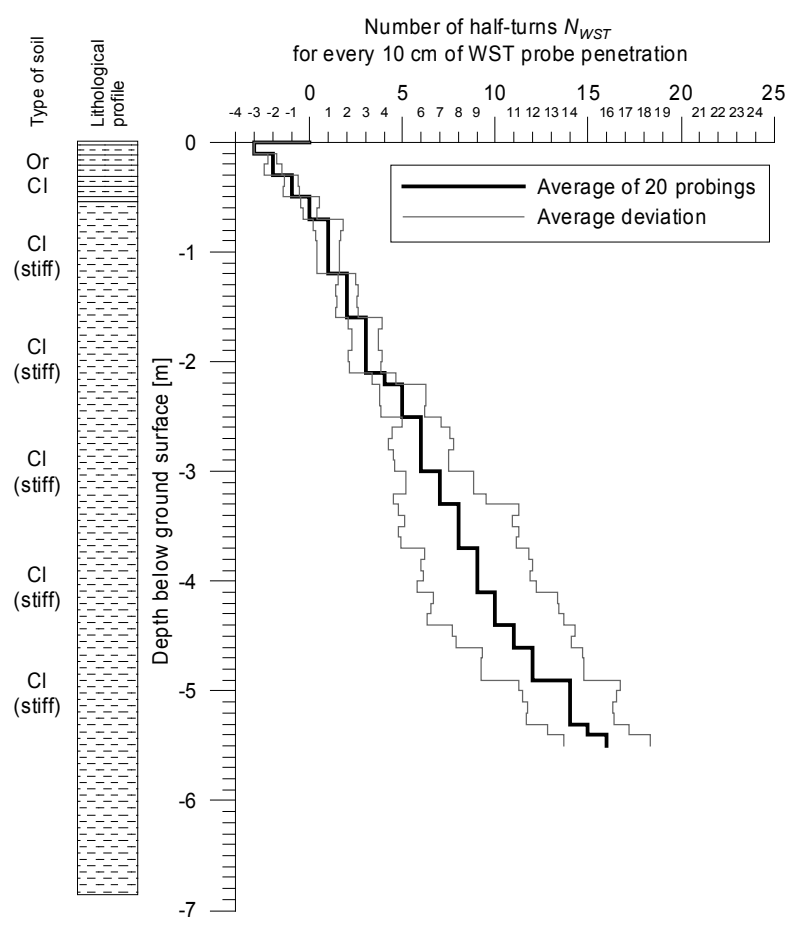

Fig. 2. Graphs of clay probing with the use of WST probe

(a) with minimum and maximum values of actual half-turn numbers, (b) with determined average deviation of half-turn numbers

Table 2

Specific results of tests carried out with the use of WST probe

\begin{tabular}{|c|c|c|c|c|}
\hline \multirow{2}{*}{ Depth } & \multicolumn{2}{|c|}{ For $30 \mathrm{~cm}$} & \multicolumn{2}{c|}{ For $50 \mathrm{~cm}$} \\
\cline { 2 - 5 } & $\begin{array}{c}\text { Number of half-turns } \\
N_{W S T}\end{array}$ & $\begin{array}{c}\text { Average } \\
\text { deviation }\end{array}$ & $\begin{array}{c}\text { Number of half-turns } \\
N_{W S T}\end{array}$ & $\begin{array}{c}\text { Average } \\
\text { deviation }\end{array}$ \\
\hline $1 \mathrm{~m}$ & 1 & 0.6 & 1 & 0.7 \\
\hline $2 \mathrm{~m}$ & 3 & 0.8 & 3 & 0.8 \\
\hline $3 \mathrm{~m}$ & 6 & 1.6 & 6 & 1.7 \\
\hline $4 \mathrm{~m}$ & 9 & 3.0 & 9 & 3.1 \\
\hline $5 \mathrm{~m}$ & 14 & 2.7 & 14 & 2.6 \\
\hline
\end{tabular}

increase of half-turn numbers from $-1(0.75 \mathrm{kN})$ to 16 on average is observed along the whole depth probed. Average deviation of the results varies considerably for individual depths and varies from 0.0 to 3.7 halfturns.
For the determination of a reliable number of halfturns at the depths from which the samples for laboratory tests were taken, an arithmetic mean value of half-turn numbers $N_{W S T}$ was obtained and calculated for sections of 30 and $50 \mathrm{~cm}$ in length. The character- 
istic results of the WST probings in the Tenczynek-2 test field are given in Table 2 .

\section{CORRELATION BETWEEN LIQUIDITY INDEX AND HALF-TURN NUMBER $N_{W S T}$}

Calibration tests were carried out in consideration of two aspects. In the first aspect, the tests referred to the liquidity index of Miocene clays determined in the laboratory and assigned to the characteristic values obtained in field tests carried out with the use of the WST probe, i.e., to the number of half-turns $N_{\text {WST }}$. The second aspect of the tests referred to selected strength properties.

For the complete characteristic and classification of the soil being investigated, a series of property determinations pursuant to the Polish Standards [24] were performed; the results of the tests are given in Table 3.

Figure 3 shows the results obtained so far in the field and laboratory tests for determination of liquidity

Results of laboratory tests of physical clay properties

(average value for the soil of the six boreholes)

\begin{tabular}{|c|c|c|c|c|c|c|}
\hline \multicolumn{2}{|c|}{ Depth } & $1 \mathrm{~m}$ & $2 \mathrm{~m}$ & $3 \mathrm{~m}$ & $4 \mathrm{~m}$ & $5 \mathrm{~m}$ \\
\hline \multicolumn{2}{|c|}{$\begin{array}{l}\text { Water content } \\
w[\%]\end{array}$} & 27.36 & 23.00 & 21.40 & 19.94 & 17.41 \\
\hline \multicolumn{2}{|c|}{$\begin{array}{l}\text { Bulk density of soil } \\
\rho\left[\mathrm{g} / \mathrm{cm}^{3}\right]\end{array}$} & 1.97 & 2.03 & 2.06 & 2.09 & 2.11 \\
\hline \multicolumn{2}{|c|}{$\begin{array}{l}\text { Density of solid particles } \\
\rho_{s}\left[\mathrm{~g} / \mathrm{cm}^{3}\right]\end{array}$} & 2.70 & 2.69 & 2.72 & 2.74 & 2.74 \\
\hline \multicolumn{2}{|c|}{$\begin{array}{l}\text { Plastic limit } \\
w_{p}[\%]\end{array}$} & 18.14 & 17.55 & 16.88 & 16.23 & 15.34 \\
\hline \multicolumn{2}{|l|}{$\begin{array}{l}\text { Liquid limit } \\
w_{L}[\%]\end{array}$} & 63.38 & 49.94 & 51.81 & 52.32 & 51.02 \\
\hline \multirow{3}{*}{ Content of: } & \begin{tabular}{|l} 
clay fraction \\
$\mathrm{Cl}[\%]$
\end{tabular} & 28.6 & 32.8 & 31.8 & 35.2 & 36.2 \\
\hline & $\begin{array}{l}\text { silt fraction } \\
\mathrm{Si}[\%] \\
\end{array}$ & 51.5 & 45.6 & 48.7 & 40.9 & 46.1 \\
\hline & $\begin{array}{l}\text { sand fraction } \\
\mathrm{Sa}[\%]\end{array}$ & 19.8 & 21.6 & 19.5 & 23.8 & 17.8 \\
\hline \multicolumn{2}{|c|}{$\begin{array}{l}\text { Liquidity index } \\
I_{L}\end{array}$} & 0.20 & 0.17 & 0.13 & 0.10 & 0.06 \\
\hline \multicolumn{2}{|c|}{ Soil consistency [26] } & stiff & stiff & stiff & stiff & stiff \\
\hline
\end{tabular}

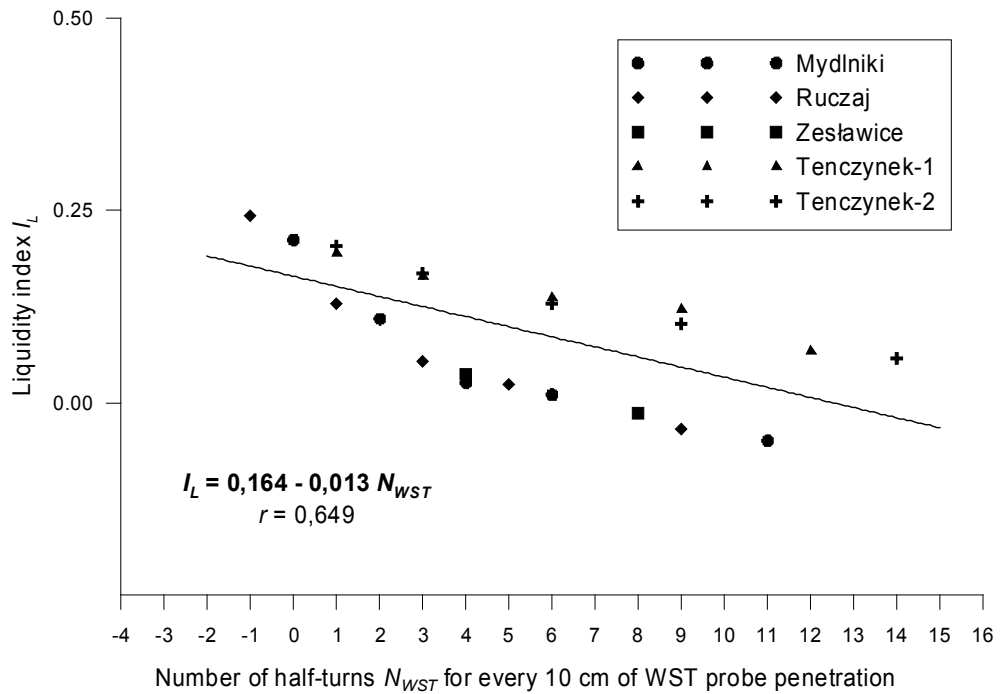

Fig. 3. Relation between liquidity index $I_{L}$ and half-turn number $N_{W S T}$ Mydlniki [20], Ruczaj [21], Zesławice [19], Tenczynek-1 [22] 
index of Miocene clays coming from the following test fields in the Kraków region: Zesławice [19], Mydlniki [20], Ruczaj [21], Tenczynek-1 [22] and extended with the results obtained in Tenczynek-2.

The results obtained confirm the linear relationship between the liquidity index and the number of half-turns $N_{W S T}$ for the soil tested

$$
I_{L}=0.164-0.013 \cdot N_{W S T}, r=0.649,
$$

where:

$I_{L}$ - liquidity index,

$N_{W S T}$ - number of half-turns,

$r$ - linear correlation coefficient.

The equation used to determine the parameters of linear regression was obtained from the constants of the straight line equation, which was estimated with the use of the least squares method. The correlation between the liquidity index and the number of halfturns $N_{W S T}$ is high $(0.5 \leq r<0,7)$, and the critical value of the linear correlation coefficient, for a significance level of 0.5 , for 22 elements, amounts to $r^{*}{ }_{0.05(22)}=$ 0.423 [8], [12]. As the calculated value of the linear correlation coefficient exceeds the critical value, an assumption may be made that there is a significant correlation between the liquidity index of the Miocene clays and the number of half-turns $N_{W S T}$.

For a proper determination of the liquidity index, based on the results of the tests carried out with the use of the WST probe, formula (1) is limited to the number of half-turns $N_{W S T}$ ranging from $-1(0.75 \mathrm{kN})$ to 14 for every $10 \mathrm{~cm}$ of probe penetration. This corresponds mainly to the Miocene clays of stiff consistency $(0.0 \leq$ $I_{L} \leq 0.25$ ), and to a limited extent, to the clays of firm $\left(I_{L} \approx 0.25\right)$ and very stiff consistency $\left(I_{L} \approx 0.0\right)$.

\section{CORRELATION BETWEEN COHESION AND ANGLE OF INTERNAL FRICTION AND HALF-TURN NUMBER $N_{W S T}$}

The main problem in soil strength tests is taking samples which truly represent the natural soil. For this purpose, samplers, which enable taking samples of unaffected structure (category A sampling methods) with the use of the fittings of the WST probe, were developed [1].

All strength tests were conducted with the triaxial testing apparatus of GDS Instruments Ltd. [1]. A UU (unconsolidated undrained) method, i.e., the tests without pre-consolidation and drainage during shearing, was used for the strength tests. Water content in the sample was kept at a constant level, and pore wa- ter pressure $u$ was measured during the tests. The tests were carried out for three pressures $\sigma_{3}=50,100$ and $200 \mathrm{kPa}$. The speed of axial displacement (share rate $v_{s}$ ) amounted to $0.01 \mathrm{~mm} / \mathrm{min}$. In addition, clay water content was determined before and after the test.

The test soil was partially saturated with water $\left(S_{r}<1\right)$ (Table 4). In which case, as the result of triaxial UU tests, Mohr's circle envelope is inclined and the values of internal friction angle are greater than zero $(\phi>0)$. Thus, based upon the results of triaxial tests, the angle of internal friction $\phi$ and cohesion $c$ of the soil tested were determined for the total stress $\sigma_{1}$ and $\sigma_{3}$, For determination of the internal friction angle and cohesion, $8-10$ average samples were taken from the same location and at the same depth and were tested for the various values of side pressure $\sigma_{3}$.

Kaczyński's studies [10], [11] demonstrate that for Miocene clays in the Carpathian Foredeep in low pressure conditions (up to $1 \mathrm{MPa}$ ), the results of the tests performed with triaxial testing apparatus may be properly interpreted in accordance with the CoulombMohr failure criterion. The strength properties of soil tested were determined with use of the equation system $q=\mathrm{f}(p)$, where $p=\frac{\sigma_{1}+\sigma_{3}}{2}$, and $q=\frac{\sigma_{1}-\sigma_{3}}{2}$ and geometrical relations between the modified parameters of $c_{T}$ and $\phi_{T}$, and the specific parameters of cohesion $c$ and an internal friction angle $\phi[4]$, [23].

For selecting results, the criterion specified in Polish Standards [24] and adapted to the assumed test method was used. The test results for specified clay groups comprised at least 6 pairs of values $p$ and $q$. For test results, two pairs representing the pressure in the chamber of 50,100 and $200 \mathrm{kPa}$, respectively were always selected. The linear correlation coefficient $r$ determined for linear relation of $q=f(p)$ had to exceed 0.9. Samples which did not meet the foregoing criterion were rejected, and strength tests were continued until 6 results meeting the assumed criterion had been obtained. Test results for the Tenczynek- 2 are given in Table 4 and in Fig. 4.

Samples taken at depths of 1 and $2 \mathrm{~m}$ were plastically deformed ("barrels") or failure occurred along slip surfaces with a considerable plastic deformation of the sample and without a clear reduction of deviatoric stress following the strain increase. A considerable plastic deformation of the samples did not allow the tests to clearly determine the angle of shearing resistance of the sample (approximately 50 to $64 \mathrm{de}$ grees) nor to describe macroscopically the shear surface. Sample failure occurs on a clear slip surface along with a decrease of soil water content, which takes place below the depth of $3 \mathrm{~m}$. The surfaces were 
Results of strength tests UU of clays

\begin{tabular}{|c|c|c|c|c|c|c|c|c|c|}
\hline \multirow{3}{*}{$\begin{array}{l}\text { Depth } \\
\text { below } \\
\text { ground } \\
\text { surface } \\
{[\mathrm{m}]}\end{array}$} & \multirow{3}{*}{$\begin{array}{c}\text { Average } \\
\text { water } \\
\text { content } \\
w[\%]\end{array}$} & \multirow{3}{*}{$\begin{array}{c}\text { Average } \\
\text { degree of } \\
\text { saturation } \\
\quad S_{r}\end{array}$} & \multirow{3}{*}{$\begin{array}{c}\text { Average } \\
\text { liquidity } \\
\text { index } \\
I_{L}\end{array}$} & \multirow{2}{*}{\multicolumn{3}{|c|}{$\begin{array}{c}\text { Parameters of } \\
\text { straight line equation } \\
q=c_{T}+\operatorname{tg} \phi_{T} \cdot p\end{array}$}} & \multirow{3}{*}{$\begin{array}{c}\text { Linear } \\
\text { correlation } \\
\text { coefficient } \\
r\end{array}$} & \multicolumn{2}{|c|}{ For total stress } \\
\hline & & & & & & & & \multirow{2}{*}{$\begin{array}{c}\text { Cohesion } \\
c \\
{[\mathrm{kPa}]}\end{array}$} & \multirow{2}{*}{$\begin{array}{c}\text { Angle of inter } \\
\text { nal friction } \\
\phi\left[^{\circ}\right]\end{array}$} \\
\hline & & & & $\begin{array}{c}c_{T} \\
{[\mathrm{kPa}]}\end{array}$ & $\operatorname{tg} \phi_{T}$ & $\begin{array}{l}\phi_{T} \\
{\left[^{\circ}\right]}\end{array}$ & & & \\
\hline 1 & 27.66 & 0.99 & 0.20 & 44.209 & 0.0898 & 5.13 & 0.990 & 44.39 & 5.14 \\
\hline 2 & 23.23 & 0.99 & 0.17 & 50.211 & 0.1263 & 7.20 & 0.965 & 50.62 & 7.22 \\
\hline 3 & 21.51 & 0.97 & 0.13 & 58.789 & 0.1481 & 8.42 & 0.941 & 59.44 & 8.45 \\
\hline 4 & 19.94 & 0.95 & 0.10 & 76.004 & 0.1761 & 9.99 & 0.988 & 77.21 & 10.04 \\
\hline 5 & 18.07 & 0.93 & 0.06 & 85.056 & 0.2425 & 13.63 & 0.986 & 87.67 & 13.76 \\
\hline
\end{tabular}

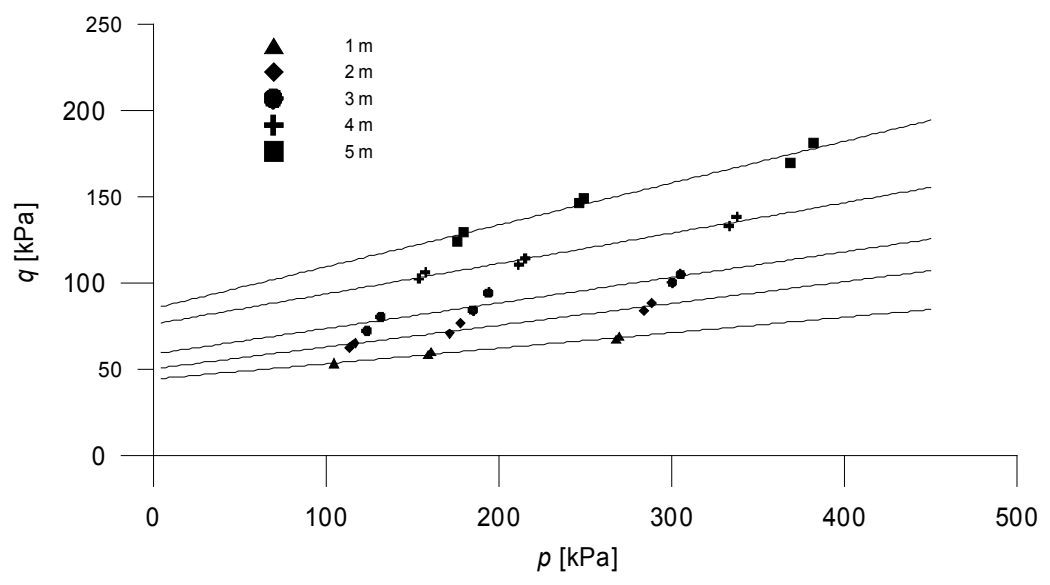

Fig. 4. Results of strength tests of clays

a)

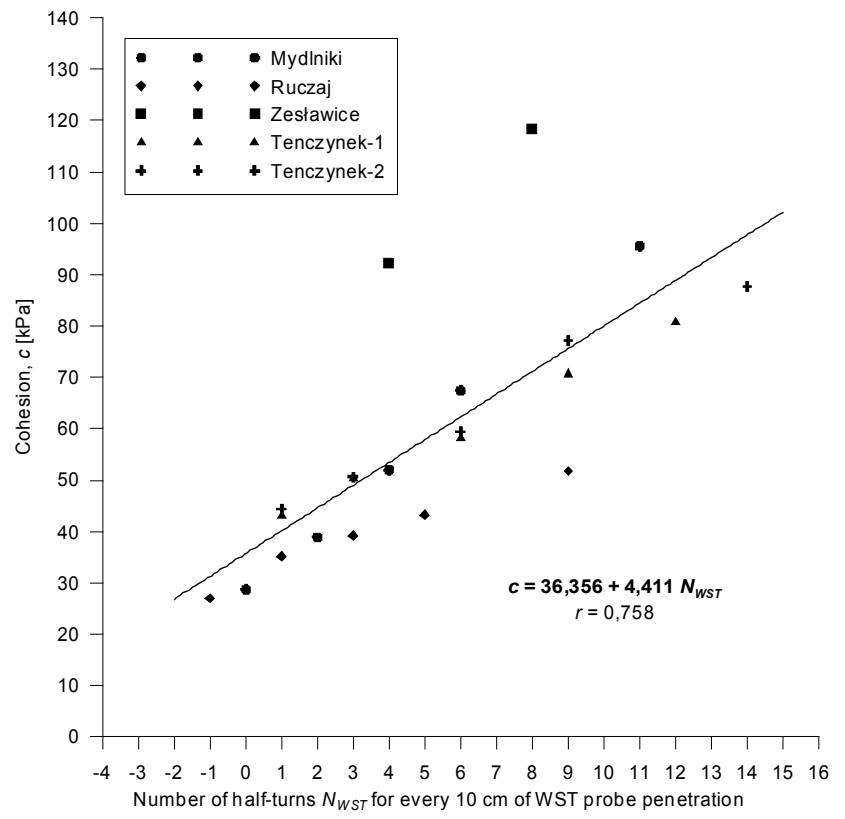

b)

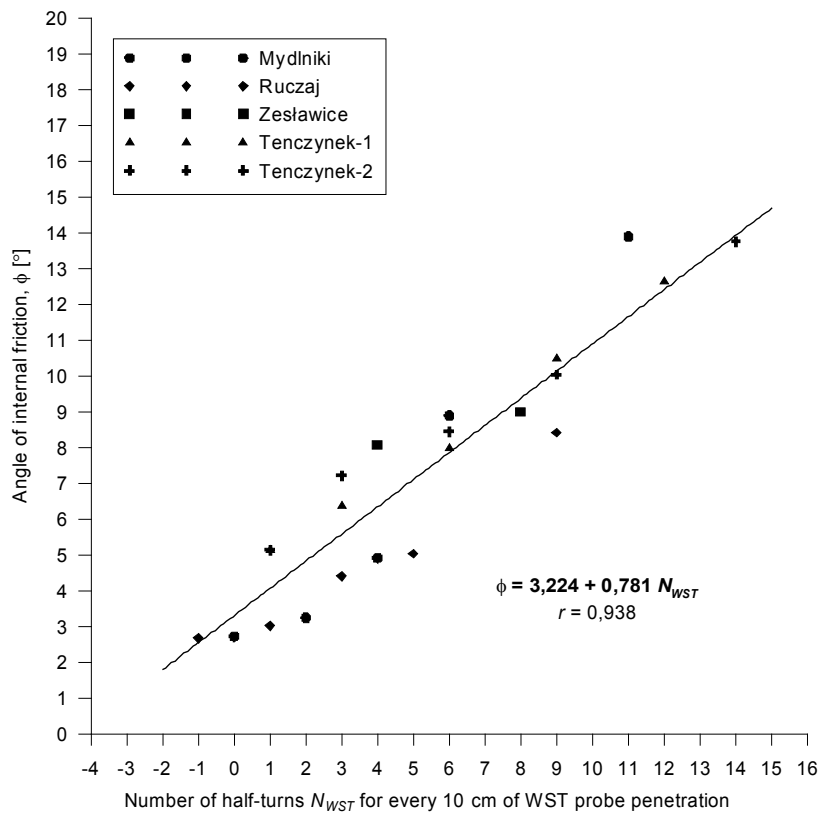

Fig. 5. Relation between cohesion and angle of internal friction and half-turn number $N_{W S T}$ (a) cohesion $c$, (b) angle of internal friction $\phi$.

Mydlniki [1], Ruczaj [1], Zesławice [1], Tenczynek-1 [22] 
uneven, slippery and glossy with clearly visible slip marks. Subject to side cell pressure $\sigma_{3}$, the angle of shearing resistance of test samples varied considerably from 44 to 67 degrees.

Figure 5 shows the results obtained so far from field and laboratory tests for the determination of selected strength properties of Miocene clays from the following test fields located in the Cracow region: Zesławice [1], Mydlniki [1], Ruczaj [1], Tenczynek-1 [22] and extended by the results obtained in Tenczynek-2.

The results confirm the linear relation between cohesion and the angle of internal friction and number of half-turns $N_{W S T}$ for Miocene clays. The following relations were found for total stress

$$
\begin{gathered}
c=36.356+4.411 \cdot N_{W S T}, r=0.758, \\
\phi=3.224+0.781 \cdot N_{W S T}, r=0.938,
\end{gathered}
$$

where:

$c$ - cohesion $[\mathrm{kPa}]$,

$\phi$ - angle of internal friction $\left[{ }^{\circ}\right]$,

$N_{W S T}$ - number of half-turns,

$r$ - linear correlation coefficient.

The parameters of the regression equation describing the relationship between the selected strength properties and half-turn number $N_{W S T}$ for tested soil were calculated from the constants of the straight line equation determined by the least squares method.

The correlation between the selected strength properties and number of half-turns $N_{W S T}$ is very high $(0.7 \leq r<0.9)$ and almost certain $(0.9 \leq r<1.0)$, and critical value of linear correlation coefficient for a significance level of 0.05 and for 22 elements amounts to $r^{*}{ }_{0.05(22)}=0.423$ [8], [12]. As the calculated values of the linear correlation coefficients exceed the critical value, a significant correlation between the tested strength properties and number of half-turns $N_{W S T}$ should be deemed to exist.

The foregoing relations (2) and (3) may be used for the determination of the selected strength properties of Miocene clays based on the WST probings for half-turn number $N_{W S T}$ ranging from $-1(0.75 \mathrm{kN})$ to 14 half-turns for every $10 \mathrm{~cm}$ of probe penetration.

\section{SUMMARY}

As laboratory tests are time-consuming and expensive, designers quite frequently replace them with quicker, and sometimes cheaper field tests. For conducting field tests with use of field equipment, proper calibration of equipment and the availability of appropriate data for the interpretation of the results obtained from the probings is required. The foregoing requirement refers to both mechanical equipment, which finds wide application in difficult geotechnical conditions, and to manually operated equipment used in simpler applications, or in sites where use of the most technically advanced automatic equipment is impossible.

Tests carried out with the use of the WST probe are among the cheapest and quickest methods of in situ soil investigations. Therefore, providing future users with universal tools for enabling the interpretation of test results to be obtained is very important. Based upon field and laboratory tests for the near-tosurface layer of Miocene clays of the Carpathian Foredeep in the Kraków region, correlation dependencies were determined, which may be subsequently used for the preparation of data and for the interpretation of the results obtained for cohesive soil.

\section{ACKNOWLEDGEMENT}

This study is supported through the statutory research registered in AGH University of Science and Technology No. 11.11.100.277.

\section{REFERENCES}

[1] Cala M., OlesiaK S., Metoda wyznaczania wybranych właściwości wytrzymałościowych iłów górnomioceńskich rejonu Krakowa na podstawie badań sonda wkręcana WST, Górnictwo i Geoinżynieria, 2011, 2, 139-148.

[2] Cubrinovski M., Geotechnical aspects of the 2010 Darfield (Canterbury) Earthquake, Bangladesh Geotechnical Conference 2010: Natural Hazards and Countermeasures in Geotechnical Engineering, 4-5 November 2010, Dhaka, Bangladesh, Proceedings of the Bangladesh Geotechnical Conference 2010, 75-85.

[3] Cubrinovski M., Orense R., Case story. 2011 Darfield (New Zealand) Earthquake: Impact of liquefaction and lateral spreading, International Society for Soil Mechanics and Geotechnical Engineering ISSMGE Bulletin, 2010, 4(4), $15-25$.

[4] DAs B.M., Advanced soil mechanics, Taylor \& Francis Group, New York, 2008.

[5] Draft international standard ISO/DIS 22476-9:2010 Geotechnical investigation and testing. Field testing. Part 9: Field vane test.

[6] Forsman J., KoIvisto K., LePpÄnen M., Case stories, Industrial and commercial areas - Deep Stabilization of the Yards of IKEA in Vantaa, Finland, International Mass Stabilization Conference 2008, October 8th - 10th 2008, Lahti, Finland, 2008.

[7] Habibi M., Cheshomi A., FAKher A., A case study of liquefaction assessment using Swedish Weight Sounding, 4th International Conference on Earthquake Engineering. Taipei, Taiwan, October 12-13, 2006, Paper No. 038.

[8] Hill T., Lewicki P., Statistics: Methods and Applications, StatSoft, Tulsa, 2007. 
[9] INADA M., Use of the Swedish type sounding test results, Soil mechanics and foundation engineering: Japanese Geotechnical Society, 1960, 8(1), 13-18 (in Japanese).

[10] KACZYŃSKI R., Wytrzymałość i odksztatcalność górnomioceńskich iłów zapadliska przedkarpackiego, Biuletyn Geologiczny, 1981, 29, 105-193.

[11] KACZYŃSKI R., Table of engineering-geological properties of miocene clays of the Carpathian Foredeep, [in:] A. Anagnostopoulos, R. Frank, N. Kalteziotis, F. Schlosser (eds.), Geotechnical engineering of hard soils - soft rocks, Proceedings of an International Symposium Under the Auspices of the International Society for Soil Mechanics and Foundation Engineering (ISSMFE), Athens, Greece, 20-23 September 1993, Vol. 1, Geological features, investigation and classification, mechanical properties, Balkema, Rotterdam, 1993, 189-194.

[12] Koт S.M., Jakubowski J., SokoŁowsKi A., Statystyka, Difin, Warszawa, 2011.

[13] Kuwano J., Ogawa., KIMURA T., AOKI H., Liquefaction hazard evaluation by Swedish Weight Sounding Test, [in:] B. Marić, Z. Lisac, A. Szavits-Nossan (ed.), Geotechnical Hazards, Proceedings of the XIth Danube-European Conference on Soil Mechanics and Geotechnical Engineering, Propeč, Croatia, 2529 May 1998, Balkema, Rotterdam, 1998, 337-342.

[14] LARSON R., Investigations and load test in silty soils. Results from a series of investigations in silty soils in Sweden, Report No. 54, Linköping, Swedish Geotechnical Institute, 1997.

[15] Matsushita K., Fujil M., TAKATA T., Damage of houses and residential areas by Niigata Prefecture Earthquake (Part 1), Proceedings of the Eighteenth (2008), International Offshore and Polar Engineering Conference, Vancouver, BC Canada, July 6-11, 2008, The International Society of Offshore and Polar Engineers (ISOPE), 2008, 743-748.

[16] MELzER K.J, BERGDAHL U., Geotechnical field investigations, [in:] U. Smoltczyk (ed.), Geotechnical engineering handbook, Vol. 1, Fundamentals, Ernst \& Sohn Verlag, Berlin, 2002.

[17] Miwa S., Aydan Ö., Komada H., Kiyono J., Endo I., Suzuki T., Hamada M., Damage in Nias Island caused by the M8.7 off-shore Sumatra Earthquake, March 28, 2005, First European Conference on Earthquake Engineering and Seismology, A joint event of the 13th ESEE \& 30th General Assembly of the ESC, Geneva, Switzerland, 3-8 Septembet 2006, Paper No. 1426.

[18] OKada K., Tomoyasu S., Muraishi H., Noguchi T., Samizo M., Correlation between soil strength of embankment surface using different sounding test, Journal of the Japanese Geotechnical Society, Soils and Foundations, 1996, 36(3), 43-50.

[19] OLESIAK S., Wykorzystanie sondy wkręcanej WST w badaniach mioceńskich iłów krakowieckich, Górnictwo i Geoinżynieria, 2009, 1, 467-473.

[20] OlesiaK S., Sonda wkręcana WST w badaniach mioceńskich iłów krakowieckich, Górnictwo i Geoinżynieria, 2010, 2, 501-507.

[21] OLESIAK S., Kalibracja sondy wkręcanej WST do badań górnomiocenskich iłów zapadliska przedkarpackiego $w$ rejonie Krakowa, Górnictwo i Geoinżynieria, 2011, 2, 463-470.

[22] OlesiaK S., Możliwości wykorzystania sondy wkręcanej WST do badań wybranych gruntów spoistych $w$ rejonie Krakowa, Inżynieria Morska i Geotechnika, 2013, 6, 534-539.

[23] Pisarczyk S., Rymsza B., Badania polowe i laboratoryjne gruntów, Oficyna Wydawnicza Politechniki Warszawskiej, Warszawa, 1993.

[24] POLSKA NORMA PN-B-04481:1988 Grunty budowlane. Badania próbek gruntu.
[25] POLSKA NORMA PN-EN 1997-2:2009 Eurokod 7. Projektowanie geotechniczne. Część 2: Rozpoznanie i badanie podłoża gruntowego.

[26] POLSKA NORMA PN-EN ISO 14688-2:2006 Badania geotechniczne. Oznaczanie i klasyfikowanie gruntów. Część 2: Zasady klasyfikowania.

[27] RANKKa K., ANDERSON-SKÖld Y., Hultén C., LARSSON R., Leroux V., Dahlin T., Quick clay in Sweden. Processes leading to formation of quick clay. Geological and hydrogeological conditions for formation of quick clay in nature. Mapping of quick clay formations by geotechnical and geophysical methods, Report No. 65, Linköping, Swedish Geotechnical Institute, 2004.

[28] Takata T., Fuji M., Matsushita K., SeKi H., Damage of houses and residential areas by Niigata Prefecture Earthquake (Part 2). Proceedings of the Eighteenth (2008) International Offshore and Polar Engineering Conference, Vancouver, BC Canada, July 6-11, 2008, The International Society of Offshore and Polar Engineers (ISOPE), 2008, $749-755$

[29] TAYlor M.L., CuBrinovsKi M., Preliminary assessment of liquefaction in urban areas following the 2010 Darfield Earthquake, Proceedings of the Ninth Pacific Conference on Earthquake Engineering: Building an Earthquake-Resilient Society, 14-16 April, 2011, Auckland, New Zealand. Paper 56, 2011.

[30] TECHNICAL SPECIFICATION ISO/TS 22476-10:2005 Geotechnical investigation and testing. Field Testing. Part 10: Weight Sounding Test.

[31] Towhata I., Ghalandarzadeh A., Shahnazari H., MOHAJERI M., SHAFIEE A., Seismic behavior of local soil and foundations in Bam City during the 2003 Bam Earthquake in Iran, Bulletin Earthquake Research Institute, University of Tokyo, 2004, 13, 69-80.

[32] Towhata I., Prasad S.K., Honda T., Chadradhara G.P., Geotechnical reconnaissance study on damage caused by 2001 Gujart Earthquake, India, Journal of the Japanese Geotechnical Society, Soils and Foundations, 2002, 42(4), 77-88.

[33] Tsukamoto Y., Ishihara K., Harada K., Evaluation of undrained shear strength of soils from field penetration test, Journal of the Japanese Geotechnical Society, Soils and Foundations, 2009, 49(1), 11-23.

[34] Tsukamoto Y., Ishihara K., SAwada S., Correlation between penetration resistance of Swedish Weight Sounding Test and SPT blow counts in sandy soils, Journal of the Japanese Geotechnical Society, Soils and Foundations, 2004, 44(3), 13-24.

[35] WAKAMATSU K., YASUdA S., Liquefaction case histories of volcanic deposit, [in:] Ishihara (ed.), Earthquake Geotechnical Engineering, Proceedings of Is-Tokyo'95, The First International Conference on Earthquake Geotechnical Engineering, Tokyo, 14-16 November 1995, Vol. 1. Balkema, Rotterdam, 1995, 19-24.

[36] Yamada S., Orense R., Cubrinovski M., Earthquake News, Geotechnical Damage due to the 2011 Christchurch, New Zealand, International Society for Soil Mechanics and Geotechnical Engineering ISSMGE Bulletin, 2011, 5(2), 27-45.

[37] Zarco M.A.H., PeCKLEY D.C., TAN S.P.V., Guidelines of the Swedish weight sounding test (SWST) in the Philippine settings, [in:] International Symposium on a Robust and Resilient Society against Natural Hazards \& Environmental Disasters and The Third AUN/Seed-Net Regional Conference on Geo-Disaster Mitigation, Kyoto University, Uji, Japan, 24-26 August 2010, 392-400. 